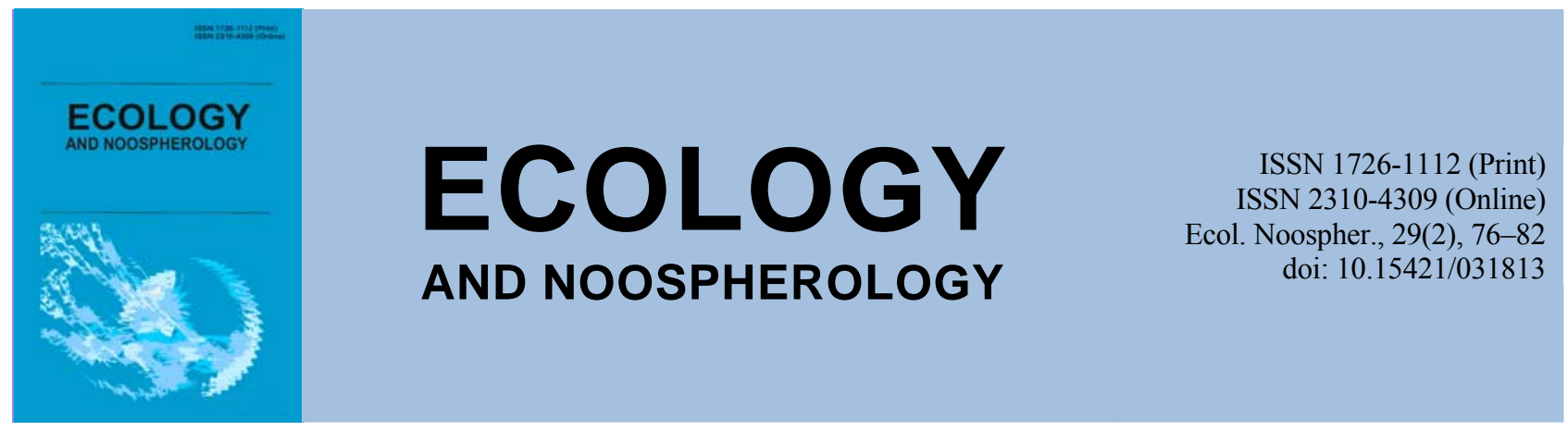

\title{
The reduction of hexavalent chromium and nitrates by Desulfuromonas YSDS-3, isolated from the soil of Yasiv sulfur mine
}

\author{
O. M. Chayka, T. B. Peretyatko \\ Ivan Franko National University of Lviv, Lviv, Ukraine
}

Article info

Received 23.09.2018

Received in revised form

29.09.2018

Accepted 30.09.2018

Ivan Franko National University of Lviv, Hrushevskoho Str., 4, Lviv, 79005, Ukraine.

Tel.: +38-067-336-47-44

E-mail:O-Chajka@i.ua
Chayka, O. M., \& Peretyatko, T. B. (2018). The reduction of hexavalent chromium and nitrates by Desulfuromonas YSDS-3, isolated from the soil of Yasiv sulfur mine. Ecology and Noospherology, 29(2), 76-82. doi:10.15421/031813

Such compounds as compounds of hexavalent chromium, nitrates and nitrites are one of the most distributed pollutants of the environment. The compounds of $\mathrm{Cr}$ (VI) are found in the soil, water and territories adjacent to mining enterprises in elevated concentrations. The hexavalent chromium has toxic, mutagenic and carcinogenic effect on living forms. Some sulfur-reducing bacteria are attractable for scientists attention like potential purification agentsto clear the wastewater from organic and inorganic pollutants. In this way,the purpose of our work is to study the patterns of the reduction of compounds of hexavalent chromium and nitrate by Desulfuromonas sp.YSDS-3, isolated from the soils of theYasiv sulfur mine. Bacteria were cultivated in modified Postgate $\mathrm{C}$ medium. To study the in fluence of $\mathrm{Cr}$ (VI) and $\mathrm{NO}_{3}$ on the sulfidogenic activity and the growth of bacteria they were grown in Postgate $\mathrm{C}$ medium containing sulfur $(32 \mathrm{mM})$ and different concentrations of $\mathrm{K}_{2} \mathrm{Cr}_{2} \mathrm{O}_{7}(0,1-1 \mathrm{MM})$ and $\mathrm{KNO}_{3}(5-15 \mathrm{MM})$, as well as without sulfur for 10 days. The biomass of bacteria, $\mathrm{Cr}$ (VI), Cr (III) and nitrites content was measured spectrophotometrically. Agar was used for the immobilization of the cells. Th ability of Desulfuromonas sp. YSDS-3 to utilize different electron acceptors, has been studied. It has been established that bacteria can growin media with presence of ferrum (III) citrate (at concentrations of $0.5 \mathrm{mM}, 1 \mathrm{mM}$ and $5 \mathrm{mM}$ ), $\mathrm{MnO}_{2}$ (at concentrations of $1 \mathrm{mM}, 2 \mathrm{mM}$ and $3 \mathrm{mM}$ ), $\mathrm{KNO}_{3}$ (at concentrations of $5 \mathrm{mM}, 10 \mathrm{mM}, 15 \mathrm{mM}$ ) and cysteine (at a concentration of $3 \mathrm{mM}$ ). In a medium with potassium bichromate bacteria grow well at concentration of $0.1 \mathrm{mM}$. Perhaps, increase of $\mathrm{K}_{2} \mathrm{Cr}_{2} \mathrm{O}_{7}$ concentration from 0.5 to $1 \mathrm{mM}$ leads to the suppression of growth and sulfidogenic activity of Desulfuromonas sp. YSDS-3. The quantitative measurement of $\mathrm{Cr}$ (VI) and $\mathrm{Cr}$ (III) ions in the cell-free medium had been shown that hexavalent chromium was completely reduced to $\mathrm{Cr}$ (III) in the presence of less than $0.5 \mathrm{mM}$ of $\mathrm{K}_{2} \mathrm{Cr}_{2} \mathrm{O}_{7}$. At the same time, the increase of $\mathrm{K}_{2} \mathrm{Cr}_{2} \mathrm{O}_{7}$ caused a decreaseof reduction effectivity. It has been found that culture of Desulfuromonas sp.YSDS-3 is able to reduce nitrates and nitrites completely. At the same time, the process of sulfur reduction was oppressed in conditions of simultaneous presence of $\mathrm{KNO}_{3}$ and sulfur in the medium. There are various methods of wastewater purification from $\mathrm{Cr}$ (VI): the addition of aerobic or anaerobic consortia of microorganisms; treatment of sewage with various sorbents, such as natural glauconites, activated carbon, brown coal, etc. The most promising methods of the environment purification from pollutants are considered to be biological methods with exertion of microorganisms. For this purpose, in modern biotechnological approaches different methods of immobilization of microorganisms with organic and inorganic carriers are widely used. It has been found some patterns of chromium reduction by the cells of Desulfuromonas sp. YSDS-3, immobilized in agar. The model solution contained $0.5 \mathrm{mM} \mathrm{Cr}$ (VI) as an electron acceptor, and sodium lactate as a donor of electrons. It has been shown that the mood of Cr (VI) usage by immobilized Desulfuromonas sp. YSDS-3 cells was similar to the one by the liquid culture. The immobilized microbiota has a number of advantages, compared to the traditional method of artificial biological treatment of sewage in aerotanks: the immobilized cells can bee asily removed from the reaction medium; all the carriers are adapted for repeateduse; the immobilization of microbial enzymatic biomass enables the increase of the catalytic activity of some enzymes. It has been shown that it is possible to use the immobilized Desulfuromonas sp. YSDS-3 cells time after time to purify the environment from $\mathrm{Cr}$ (VI) pollutant.The cells of Desulfuromonas sp. YSDS-3 (the amount of cells was $1 \mathrm{~g} / \mathrm{L}$ ) completely reduced $\mathrm{Cr}$ (VI) to $\mathrm{Cr}$ (III) after 72 hours in the conditions of model medium addition containing $0.5 \mathrm{mM} \mathrm{K}_{2} \mathrm{Cr}_{2} \mathrm{O}_{7}$. Afterre-injection of $0.5 \mathrm{mM} \mathrm{K}_{2} \mathrm{Cr}_{2} \mathrm{O}_{7}$ in 72 hours, the reduction efficiency was about $70 \%$. 
Subsequent addition of $0.5 \mathrm{mM} \mathrm{Cr}$ (VI) led to lower reduction rate of $\mathrm{Cr}$ (VI): nearby $57 \%$. The rate of reduction of $\mathrm{Cr}(\mathrm{VI})$ depends on the concentration of the immobilized cells. With the increase of the amount of immobilized cells $(2 \mathrm{~g} / \mathrm{L}, 3 \mathrm{~g} / \mathrm{L}, 5 \mathrm{~g} / \mathrm{L})$, it was observed more intense reduction of $\mathrm{Cr}(\mathrm{VI})$. The working concentration of the cells of Desulfuromonas sp. YSDS-3 about $5 \mathrm{~g} / \mathrm{L}$ is the fit amount of bacteria for the most efficient reduction of $\mathrm{Cr}$ (VI). After the third introduction of the model solution, the reduction efficiency was $67 \%$ after 72 hours of incubation. The duration and intensity of chromium reduction were directly dependent on the concentration of immobilized cells: if the amount of fixed cells was higher, the recovery process was more effective. The immobilized Desulfuromonas sp. YSDS-3 cells can completely detoxicate $\mathrm{Cr}$ (VI) in amount of $0.5 \mathrm{mM}$ in 72 hours. The increase of the concentration of the cells accelerates the process of chromate utilization in the model solution. So, Desulfuromonas sp. YSDS-3 is promising for an aerobic treatment of the sewage from chromium-containing compounds.

Keywords: sulfur-reducing bacteria; elemental sulfur; chromate ion; sulfidogenic activity; immobilized microorganisms

\title{
Відновлення сполук шестивалентного хрому і нітрату бактеріями Desulfuromonas SP.YSDS-3, виділених із грунту Язівського родовища сірки
}

\author{
О. М. Чайка, Т. Б. Перетятко \\ Львівський національний університет імені Івана Франка, Львів, Украӥна
}

У даній роботі проаналізовано результати досліджень відновлення сполук шестивалентного хрому і нітрату бактеріями Desulfuromonas sp.YSDS-3. Досліджено здатність Desulfuromonas sp. YSDS-3 використовувати різні акцептори електронів $\left(\mathrm{MnO}_{2}, \mathrm{KNO}_{3}\right.$, ферум (III) цитрат, калій біхромат) у процесі росту. Установлено вплив сполук $\mathrm{Cr}(\mathrm{VI}) \mathrm{Ta} \mathrm{NO}_{3}^{-}$на ріст i сульфідогенну активність бактерій Desulfuromonas sp. YSDS-3. Встановлено деякі закономірності відновлення хромат-йону залитими в агар клітинами Desulfuromonas sp. YSDS-3.

Ключові слова: сірковідновлювальні бактерії, елементна сірка, хромат-йон, сульфідогенна активність, іммобілізовані клітини

ВстуіI

Сірковідновлювальні бактерії відновлюють елементну і полісульфідну форми сірки до гідроген сульфіду у місцях, збагачених сіркою (сірковидобувних регіонах, безкисневих осадах морських та прісноводних водойм, гідротермальних джерелах, вулканічних гарячих джерелах), використовуючи молекулярний водень або органічні субстрати як донори електронів. Деякі представники сірковідновлювальних бактерій, крім елементної сірки, як акцептор електронів можуть використовувати метали зі змінною валентністю (Fe (III), Mn (IV), нітрати, цистеїн, метіонін, малат, фумарат, трихлоретилен чи тетрахлоретилен (Lovley, 1993; An, Picarda, 2015).

Гідроген сульфід, що утворився в процесі сіркоредукції, здатний осаджувати йони важких металів $\left(\mathrm{Co}^{2+}, \mathrm{Ni}^{2+}, \mathrm{Cd}^{2+}, \mathrm{Fe}^{3+}, \mathrm{Pb}^{2+}, \mathrm{Zn}^{2+}, \mathrm{Hg}^{2+}\right.$ та ін.) у формі неорганічних сульфідів, сприяючи очищенню водойм від цих йонів (Lovley, 1993). Сірковідновлювальні бактерії $€$ високоефективними біокаталізаторами мікробно-анодних паливних елементів, що забезпечують генерування електричного струму під час окиснення органічних сполук (Bilyy, Vasyliv, Hnatush, 2014).

Сполуки $\mathrm{Cr}$ (VI) виявляють у підвищених концентраціях у грунті, воді, особливо на територіях, прилеглих до індустріальних міст і підприємств гірничовидобувної промисловості. Сполуки шестивалентного хрому, нітрати і нітрити - одні з найбільш поширених забруднювачів навколишнього середовища. Шестивалентний хром виявляє токсичну, мутагенну та канцерогенну дію на живі організми, пришвидшує процеси апоптозу (ЕРА, 1998).

Існують різні способи очищення стічних вод від $\mathrm{Cr}$ (VI): використання консорцій мікроорганізмів; оброблення стічних вод різними сорбентами - природними глауконітами, активованим вугіллям, бурим вугіллям тощо (Camargo, et. al., 2003, Horton, et. al. 2006, Sholiak, Peretyatko, Gudz, S. P., 2014, Smith, Gadd, 2000, Vasylinych, 2011, Shanna, Forster, 1996, Anyanwu, Ezaka, 2011). Найбільш перспективними методами очищення навколишнього середовища від полютантів вважають біологічні методи з використанням мікроорганізмів (Smith, Gadd, 2000).

Анаеробні процеси використовуються для очищення стоків уже більше 100 років. Перевагами використання анаеробних процесів $\epsilon$ мала потреба у поживних речовинах внаслідок нагромадження анаеробними мікроорганізмами невеликої біомаси; зниження витрат електроенергії та, на відміну від аеробних систем, анаеробні не дуже вибагливі до обмеження акцептора електронів, тому завантаження систем може бути вищим, ніж для аеробних систем (Seghezzo, 1998). Основними недоліками застосування очисних систем на основі анаеробних мікроорганізмів $\epsilon$ низька швидкість їх росту і невелика біомаса.

Сірковідновлювальні бактерії привертають увагу науковців як потенційні агенти очищення стічних вод від полютантів органічної і неорганічної природи, тому метою роботи було дослідити закономірності відновлення сполук шестивалентного хрому i нітрату бактеріями Desulfuromonas sp.YSDS-3, виділених з грунту Язівського родовища сірки.

\section{Матеріали та методи досліджень}

У роботі використовували сірковідновлювальні бактерії Desulfuromonas sp. YSDS-3, виділені 3 грунту Язівського родовища сірки (Яворівський район, Львівська область, Україна) (Chayka, Peretyatko, Gudz, 2010). Бактерії вирощували у модифікованому середовищі Постгейта $\mathrm{C}$ такого складу (г/л): $\mathrm{KH}_{2} \mathrm{PO}_{4}-0,5 ; \mathrm{NH}_{4} \mathrm{Cl}-1,0 ; \mathrm{CaCl}_{2} \cdot 6 \mathrm{H}_{2} \mathrm{O}-0,06$; 
$\mathrm{MgCl}_{2} \cdot 6 \mathrm{H}_{2} \mathrm{O}-0,05$; натрій лактат - 6; дріжджовий екстракт $-1,0$; натрій лимоннокислий $-0,3$; аскорбінова кислота $-1,0$; елементна сірка - 1,0 , вода дистильована до 1 л; pH 7,5 (Postgate,1984). Середовище стерилізували за 0,75 атм протягом 30 хв і розливали у пробірки (25 мл), закривали стерильними гумовими корками. Середовище засівали суспензією клітин у концентрації 0,2 г/л і культивували за $30{ }^{0} \mathrm{C}$ упродовж 5-14 діб. Біомасу клітин визначали турбідиметрично на фотоелектроколориметрі КФК -3 ( $\lambda=340$ нм, $\ell=3$ мм). Вміст гідроген сульфіду визначали фотоелектроколометрично за утворенням метиленової сині (Sugiyama, 2002)

Для дослідження здатності Desulfuromonas sp. YSDS-3 відновлювати $\mathrm{Fe}$ (III), $\mathrm{MnO}_{2}, \mathrm{NO}_{3}{ }^{-}, \mathrm{Cr}$ (VI), цистеїн і трихлоретилен їх вирощували у середовищах без сірки, до якого додавали $\mathrm{Fe}$ (III) цитрат (у концентрації 0,5 мМ, $1 \mathrm{mM}$ і $5 \mathrm{MM}$ ), $\mathrm{MnO}_{2}$ (у концентрації $1 \mathrm{mM}, 2 \mathrm{MM}$ і $3 \mathrm{MM}$ ), $\mathrm{KNO}_{3}$ (у концентрації $5 \mathrm{mM}, 10 \mathrm{mM} \mathrm{i} 15 \mathrm{MM}$ ), $\mathrm{K}_{2} \mathrm{Cr}_{2} \mathrm{O}_{7}$ (у концентрації 0,1 мМ, 0,5 мМ і 1 мM), цистеїн (у концентрації 3 мМ) і трихлоретилен (у концентрації 0,1 мМ, 0,5мM), і культивували протягом 10 діб. Контролем слугувало середовище з елементною сіркою.

Для дослідження впливу сполук $\mathrm{Cr}$ (VI) та $\mathrm{NO}_{3}{ }^{-}$на Desulfuromonas sp. YSDS-3 їх вирощували у середовищі Постгейта $\mathrm{C} 3$ елементною сіркою (32 мМ) i різними концентраціями $\mathrm{K}_{2} \mathrm{Cr}_{2} \mathrm{O}_{7}(0,1-1 \mathrm{MM})$ i $\mathrm{KNO}_{3}(5-15 \mathrm{MM})$, а також без сірки упродовж 10 діб.

Для одержання фіксованих в агарі клітин Desulfuromonas sp. YSDS-3 бактерії центрифугували протягом 30 хв за 6000 g. Клітини відмивали ізотонічним розчином натрій хлориду. Клітини у концентрації 1,3 , 5 г/л вносили в 2\%-й розчин агару. Агаризований розчин рівномірним шаром розливали у чашки Петрі. Після застигання агару зафіксовані клітини формували у вигляді кубиків $(10 \times 10$ мм) та вносили у модельний розчин. Модельний розчин містив $0,5 \mathrm{mM} \mathrm{Cr}$ (VI) як акцептор електронів та лактат натрій як донор електронів.

Вміст Cr (VI) визначали колориметрично ( $\lambda=540 \mathrm{Hм}$, $\ell=10$ мм) за дифенілкарбазидним методом (Marchart, 1964). Для визначення $\mathrm{Cr}$ (III) використовували хромазурол $\mathrm{S}$ ( $\lambda=590$ нм, довжина $\ell=10$ мм) (Honchar, et. al., 2008).

Вміст нітриту в культуральній рідині визначали спектрофотометрично $(\lambda=540$ нм, $\quad \ell=10$ мм $) 3$ використанням $\mathrm{n}$-нафтилендіаміндихлориду. Концентрацію нітрату визначали після діазотування нітриту в культуральній рідині. Як відновник використовували цинковий порошок (Granger, Taintor, Boockvar, 1996).

Індол визначали за методом Ковача (Derzhavna farmakopeia Ukrainy. I vydannia, 2001).

Результати представлені як середнє значення 3 поправкою на стандартну похибку $(\mathrm{M} \pm \mathrm{m})$. Достовірність описаних результатів визначали за t-критерієм Стьюдента (Gumec'kyj, Paljanycja, Chaban, 2004). Статистичне опрацювання результатів проводили, використовуючи програми «Microsoft Excel 2010», «Origin 6.1».

\section{Результати та їх обговорення}

3 грунту Язівського родовища сірки виділено паличкоподібні сірковідновлювальні бактерії Desulfuromonas sp. YSDS-3, які добре ростуть у синтетичному середовищі 3 елементною сіркою за температури $25-30{ }^{\circ} \mathrm{C}$ i pH 6,5-7,5 (Chayka, Peretyatko, Gudz, 2010).

Дослідили здатність Desulfuromonas sp. YSDS-3 використовувати різні акцептори електронів у процесі росту в рідкому модифікованому середовищі Постгейта $\mathrm{C}$, донором електронів у ньому був лактат, а акцепторами $\mathrm{MnO}_{2}, \quad \mathrm{KNO}_{3}$, ферум (III) цитрат, калій біхромат. Встановлено, що бактерії ростуть у середовищі з ферум (III) цитратом (за концентрації 0,5 мM, $1 \mathrm{MM}$ і $5 \mathrm{MM}$ ), $\mathrm{MnO}_{2}$ (за концентрації 1 мМ, 2 мM і $3 \mathrm{MM}$ ), $\mathrm{KNO}_{3}$ (за концентрації
5 мМ, 10 мМ, 15мМ) і цистеїном (за концентрації 3 мМ) (рис. 1). У середовищі з калій біхромату бактерії ростуть за його концентрації 0,1 мМ (рис. 1). Зростання концентрації $\mathrm{K}_{2} \mathrm{Cr}_{2} \mathrm{O}_{7}$ до $0,5 \mathrm{mM}$ призводило до пригнічення росту бактерій удвічі. 3 даних літератури відомо, що більшість штамів бактерій роду Desulfuromonas не відновлюють $\mathrm{Cr}$ (VI) i $\mathrm{NO}_{3}{ }^{-}$як акцептори електронів. Бактерії D. carbonis, i D. palmitatis можуть відновити 50 мМ ферум (III) цитрату i $20 \mathrm{MM} \mathrm{MnO}_{2}$ (An, Picarda, 2015).

Відомо, що сульфатвідновлювальні бактерії Desulfomicrobium sp. CrR3 ростуть за концентрації $\mathrm{K}_{2} \mathrm{Cr}_{2} \mathrm{O}_{7}$ 1 мМ і нітрату 12 мМ (Sholiak, Peretyatko, Gudz, 2013).

У результаті дослідження впливу сполук $\mathrm{KNO}_{3}$ на ріст i утворення гідроген сульфіду Desulfuromonas sp. YSDS-3 встановлено, що після чотирьох діб культивування нітрати і нітрити повністю відновлюються бактеріями. Найбільшу біомасу бактерії нагромаджували у середовищі 3 елементною сіркою і $\mathrm{KNO}_{3}(1$ г/л). Однак за таких умов (3 $\mathrm{KNO}_{3}$ ) бактерії нагромаджували у 2 рази менше гідроген сульфіду, ніж у середовищі з елементною сіркою (рис. 2). Отже, одночасна наявність двох акцепторів електронів, $\mathrm{KNO}_{3}$ і елементної сірки супроводжувалась інгібуванням сіркоредукції.

У середовищі 3 елементною сіркою $\mathrm{i} \mathrm{K}_{2} \mathrm{Cr}_{2} \mathrm{O}_{7}$ у концентрації 0,1 мМ бактерії нагромаджували 0,8 г/л біомаси на 10-ту добу (рис. 3, а). Зростання концентрації $\mathrm{K}_{2} \mathrm{Cr}_{2} \mathrm{O}_{7}$ до 0,5 мМ у середовищі 3 елементною сіркою призводило до пригнічення росту бактерій (рис. 3, а). За концентрації $\mathrm{K}_{2} \mathrm{Cr}_{2} \mathrm{O}_{7} 1 \mathrm{mM}$ біомаса бактерії не зростала (рис. 3, а). Кількісне визначення йонів $\mathrm{Cr}$ (VI) і $\mathrm{Cr}$ (III) у культуральній рідині показало, що за концентрації $0,1 \mathrm{mM} \mathrm{i}$ 0,5 мМ $\mathrm{K}_{2} \mathrm{Cr}_{2} \mathrm{O}_{7}$ бактерії повністю відновлювали йони шестивалентного хрому до тривалентного, а за концентрації 1 мМ лише - $38 \%$ від початкової концентрації $\mathrm{K}_{2} \mathrm{Cr}_{2} \mathrm{O}_{7}$ (рис. 3, б). Одержані результати вказують на те, що за концентрації 0,5-1 мМ $\mathrm{K}_{2} \mathrm{Cr}_{2} \mathrm{O}_{7}$ пригнічує ріст і сульфідогенну активність Desulfuromonas $\mathrm{sp}$. YSDS-3. Відомо, що бактерії Bacillus sp., Pseudomonas sp., Escherichia coli i Staphylococcus sp., виділені 3 води очисних споруд, толерантні до високої концентрації $\mathrm{Cr}$ (VI) (до 500 мкг/мл) (Owlad, et. al., 2009). Для сульфатвідновлювальних бактерій Desulfomicrobium sp $\mathrm{CrR} 3 \mathrm{Cr}$ (VI) у концентрація $0,5-1$ мМ не впливала на ріст бактерій. Збільшення концентрації $\mathrm{Cr}$ (VI) до 2-3 мМ пригнічувало ріст бактерій удвічі. Сульфатвідновлювальні бактерії Desulfotomaculum reducens sp. nov. MI-1 можуть відновити лише 60 мкM Cr (VI) (Kofanov, Ohnianyk, 2009.).

Дослідження впливу $\mathrm{K}_{2} \mathrm{Cr}_{2} \mathrm{O}_{7}$ на ріст Desulfuromonas sp. YSDS-3 у середовищі 3 калій біхроматом без елементної сірки показало, що в концентрації $0,1 \mathrm{MM} \mathrm{і} 0,5 \mathrm{mM} \mathrm{K}_{2} \mathrm{Cr}_{2} \mathrm{O}_{7}$ пригнічує ріст у 1,5 і 3 рази відповідно порівняно із контролем. За концентрації $\mathrm{K}_{2} \mathrm{Cr}_{2} \mathrm{O}_{7} 1 \mathrm{мM}$ бактерії не росли (рис. 4).

Кількісне визначення йонів $\mathrm{Cr}$ (VI) i $\mathrm{Cr}$ (III) у культуральній рідині показало, що за концентрації $\mathrm{K}_{2} \mathrm{Cr}_{2} \mathrm{O}_{7}$ 0,1 мМ бактерії повністю відновили йони шестивалентного хрому до тривалентного, а за концентрації $0,5 \mathrm{mM} \mathrm{i} 1 \mathrm{mM}$ бактерії відновили лише 0,3 мМ (рис. 4). Очевидно, пригнічення нагромадження біомаси і гідроген сульфіду обумовлено токсичним впливом $\mathrm{K}_{2} \mathrm{Cr}_{2} \mathrm{O}_{7}$ на бактерії. Одержані результати вказують на те, що досліджувані бактерії можуть відновлювати високотоксичний шестивалентний хром до малотоксичного Сr (III).

У сучасних біотехнологічних підходах щодо розроблених біологічних методів очищення забруднених вод широко використовуються різні методи іммобілізації мікроорганізмів на носіях (Owlad, et. al., 2009). Порівняно 3 традиційним методом штучного біологічного очищення стічних вод в аеротенках іммобілізована мікробіота має низку переваг: іммобілізовані клітини легко вилучити 3 реакційного середовища, носії пристосовані до 


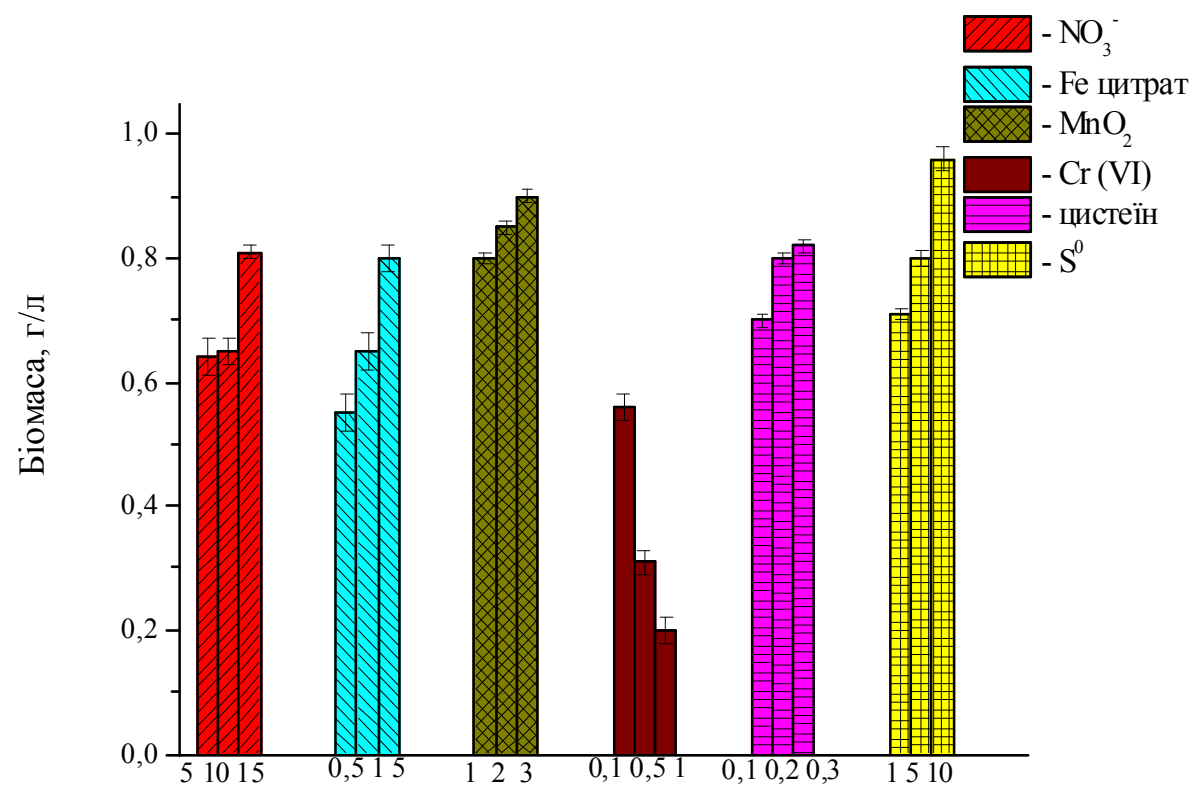

Концентрація акцептора електронів, мМ

Рис. 1. Нагромадження біомаси Desulfuromonas sp. YSDS-3 за наявності в середовищі різних акцепторів електронів

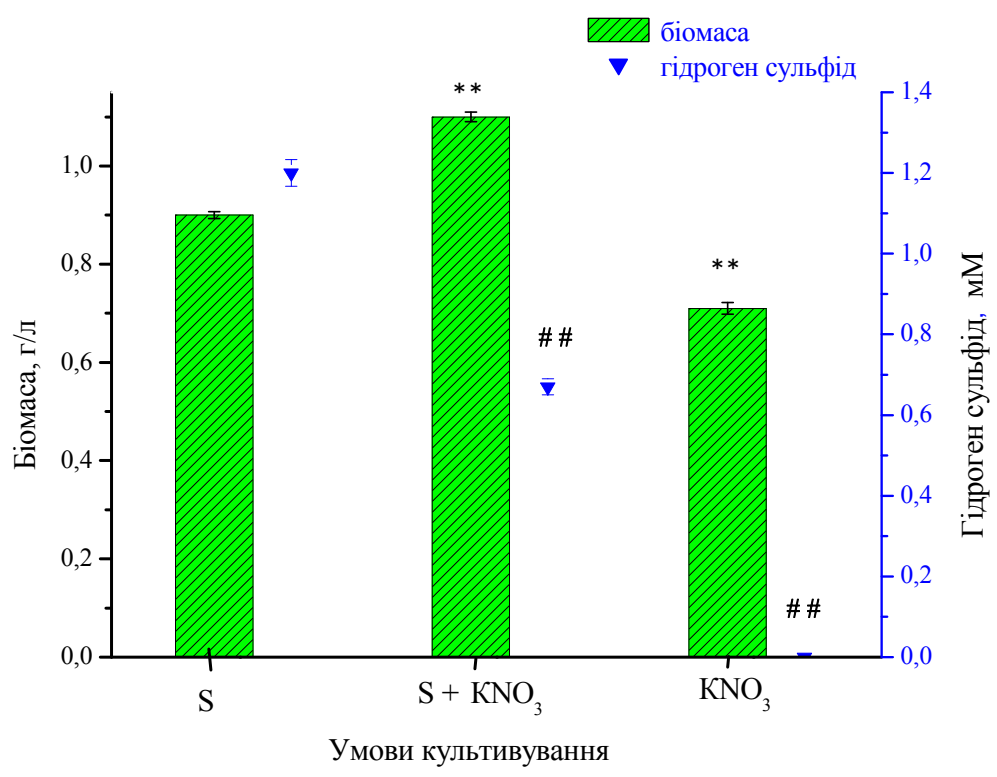

Рис. 2. Нагромадження біомаси і гідроген сульфіду Desulfuromonas sp. YSDS-3 у середовищах з елементною сіркою, $\mathrm{KNO}_{3}$ і елементною сіркою і лише з $\mathrm{KNO}_{3}$.

Примітка. * $\mathrm{P}<0,01$ - вірогідні зміни концентрації гідроген сульфіду порівняно з контролем; \# ${ }^{\mathrm{P}<0,01}$ - вірогідні зміни біомаси порівняно з контролем.

багаторазового використання, іммобілізація мікробної ферментативної біомаси дає змогу підвищити каталітичну активність ферментів (Owlad, et. al., 2009).

Дослідили деякі закономірності відновлення хроматйону залитими в агар клітинами бактерій Desulfuromonas sp. YSDS-3. Закономірності використання Cr (VI) залитими в агарі клітинами бактерій Desulfuromonas sp. YSDS-3 є подібними до використання $\mathrm{Cr}$ (VI) нефіксованими клітинами (табл. 1).

Швидкість відновлення $\mathrm{Cr}$ (VI) залежить від концентрації клітин, залитих в агар (рис. 5). Перевагами використання іммобілізованих клітин порівнято із суспензійними $є$ їх багаторазове застосування. Іммобілізовані в агар клітини Desulfuromonas sp. YSDS-3 можуть кількаразово використовуватись для очищення середовища від $\mathrm{Cr}$ (VI). Як видно 3 рис. 5, клітини Desulfuromonas sp. YSDS-3 у концентрації 1 г/л, після внесення модельного середовища, яке містило $0,5 \mathrm{mM}$ $\mathrm{K}_{2} \mathrm{Cr}_{2} \mathrm{O}_{7}$, повністю відновили $\mathrm{Cr}$ (VI) до $\mathrm{Cr}$ (III) через 72 години. Після повторного внесення $0,5 \mathrm{mM} \mathrm{K}_{2} \mathrm{Cr}_{2} \mathrm{O}_{7}$ на 72-ту годину ефективність відновлення становила $70 \%$. 3 наступним внесенням 0,5 мM Cr (VI) спостерігали ще меншу інтенсивність відновлення Cr (VI) - 57 \%.

Із зростанням концентрації залитих в агар клітин у модельний розчин, що містив 0,5 мМ $\mathrm{K}_{2} \mathrm{Cr}_{2} \mathrm{O}_{7}$, спостерігали більш інтенсивне відновлення $\mathrm{Cr}$ (VI) (рис. 5). Уже через 24 год. Desulfuromonas sp. YSDS-3 нагромадили 0,49 мM Cr (III). Повторне внесення 0,5 мM $\mathrm{K}_{2} \mathrm{Cr}_{2} \mathrm{O}_{7}$ 


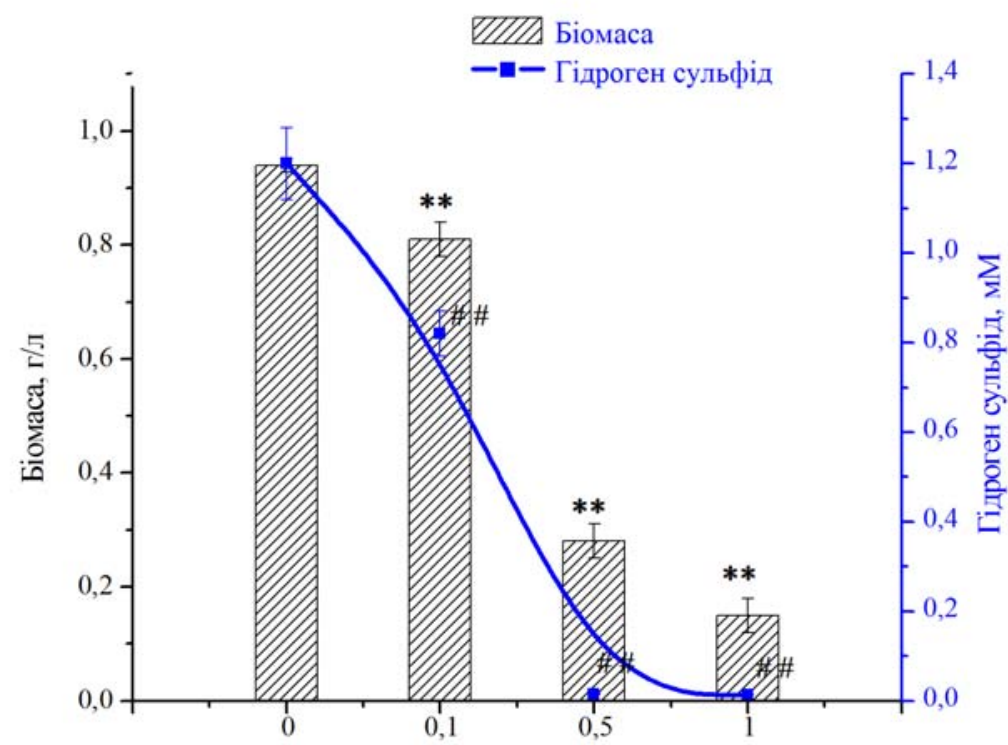

Концентрація $\mathrm{K}_{2} \mathrm{Cr}_{2} \mathrm{O}_{7}$, мM

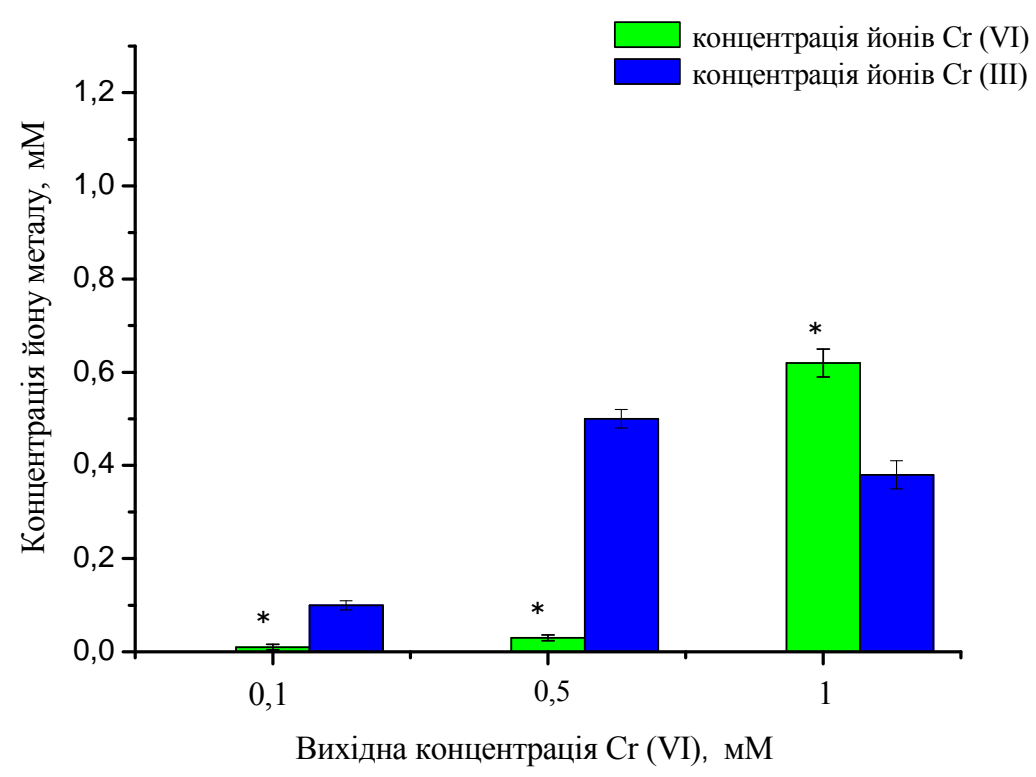

6

Рис. 3. Нагромадження біомаси, гідроген сульфіду (a) та використання йонів Cr (VI) (б) Desulfuromonas sp. YSDS-3 у середовищах 3 елементною сіркою і $\mathrm{K}_{2} \mathrm{Cr}_{2} \mathrm{O}_{7}$ і без додавання калій біхромату.

Примітка. * $\mathrm{P}<0,05$; ** $\mathrm{P}<0,01$ - вірогідні зміни біомаси і концентрації йонів $\mathrm{Cr}$ (VI) порівняно 3 контролем; \#\# $\mathrm{P}<0,05 ;{ }^{\#} \mathrm{P}<0,01$ - вірогідні зміни концентрації гідроген сульфіду порівняно з контролем.

призводило до сповільнення використання $\mathrm{Cr}$ (VI) клітинами бактерій удвічі. 3 наступним внесенням 0,5 мМ $\mathrm{Cr}$ (VI) ефективність відновлення становила $67 \%$.

Найбільш ефективно бактерії Desulfuromonas sp. YSDS-3 відновлюють Cr (VI) за концентрації клітин 5 г/л (рис. 5). Після 24 годин бактерії повністю відновили $\mathrm{Cr}$ (VI). Після повторного внесення $0,5 \mathrm{мM} \mathrm{K} \mathrm{Cr}_{2} \mathrm{O}_{7}$ бактерії повністю відновили $\mathrm{Cr}(\mathrm{VI})$ через 72 год. А після третього внесення середовища - спостерігали незначне зменшення інтенсивності відновлення хрому $\mathrm{Cr}(\mathrm{VI})$, за цих умов у середовищі бактерії нагромадили 0,48 мM Cr (III).

Існують численні методи очищення хромвмісних стічних вод: іонообмінні, сорбційні, мембранні, електрохімічні, біологічні (Owlad, et. al., 2009). Кожний 3 методів має свої недоліки: мембранний - низька хімічна стійкість мембран в агресивних середовищах, постійне забруднення; сорбційний - ускладнення регенерації та повторного використання сорбенту, чим вища якість очищення, тим більша вартість; іонообмінний концентрацію розчину слід контролювати; електрохімічний - утворення осадів. Біологічний метод $\epsilon$ один 3 найефективніших під час очищення стічної води від йонів неорганічних сполук. Він має свої переваги та недоліки, один з яких - достатньо тривалий час окиснення забруднювальних речовин (Owlad, et. al., 2009). Ліквідувати ці недоліки можна за допомогою методів інтенсифікації процесу шляхом іммобілізації клітин.

Сірковідновлювальні бактерії Desulfuromonas sp. YSDS-3, виділені з грунту Язівського родовища сірки за відсутності елементної сірки, як акцептори електронів 


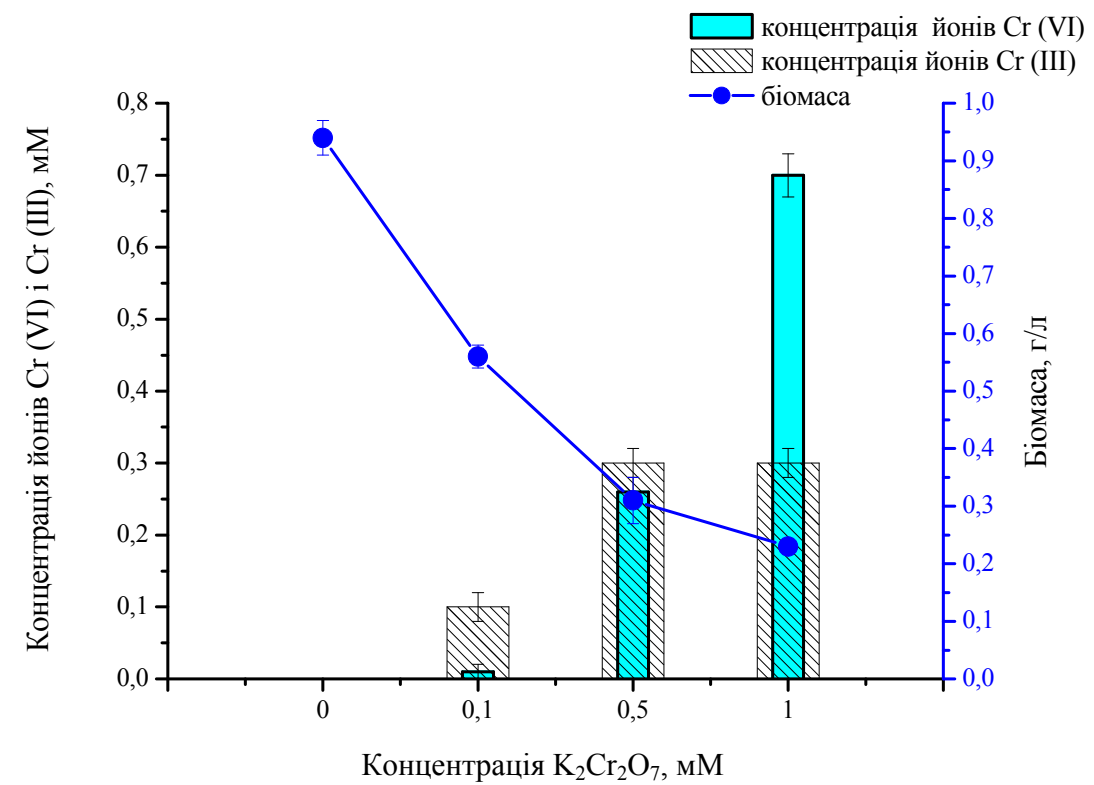

Рис. 4. Нагромадження біомаси та використання йонів Cr (VI) Desulfuromonas sp. YSDS-3 за різної концентрації $\mathrm{K}_{2} \mathrm{Cr}_{2} \mathrm{O}_{7}$ Примітка. * $\mathrm{P}<0,05$; ** $\mathrm{P}<0,01$ - вірогідні зміни біомаси і концентрації йонів $\mathrm{Cr}$ (VI) порівняно з контролем.

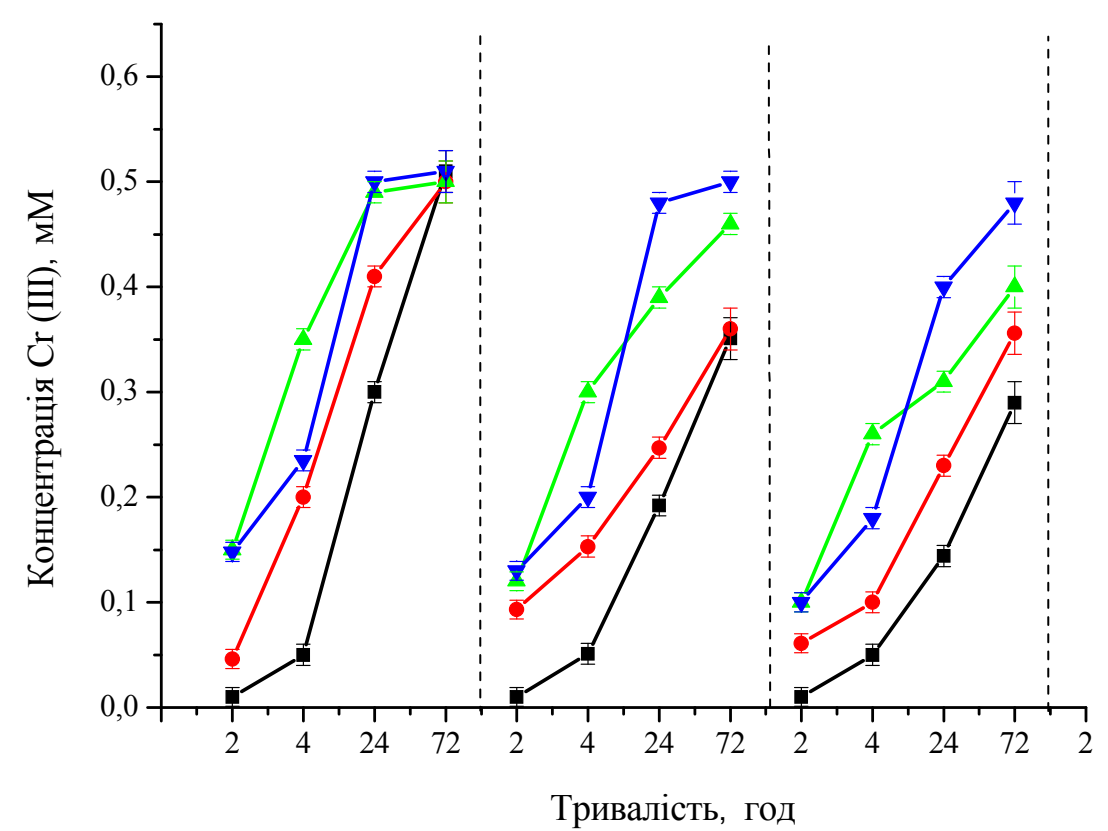

Рис. 5. Використання 0,5 мМ Cr (VI) залитими в агар клітинами бактерій Desulfuromonas sp. YSDS-3

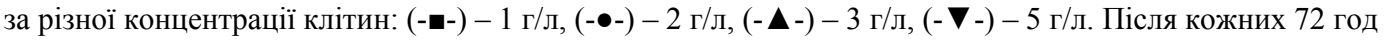
інкубації вносили модельний розчин $\mathrm{Cr}(\mathrm{VI})$, вихідна концентрація $\mathrm{Cr}$ (VI) 0,5 мM

\section{Таблиця 1}

Відновлення Cr (VI) до Cr (III) суспензійними та іммобілізованими клітинами Desulfuromonas sp. YSDS-3*

\begin{tabular}{ccccc}
\hline \multirow{2}{*}{$\begin{array}{c}\text { Тривалість } \\
\text { культивування/інкубування, } \\
\text { год }\end{array}$} & \multicolumn{2}{c}{$\begin{array}{c}\text { Суспензійні клітини Desulfuromonas sp. } \\
\text { YSDS-3 }\end{array}$} & $\begin{array}{c}\text { Iммобілізовані клітини Desulfuromonas sp. } \\
\text { YSDS-3 }\end{array}$ \\
\cline { 2 - 5 } & \multicolumn{4}{c}{ Концентрація йонів хрому, мM } \\
\hline 0 & $0,51 \pm 0,02$ & $\mathrm{Cr}(\mathrm{III})$ & $0,51 \pm 0,02$ & $\mathrm{Cr}$ (III) \\
\hline 2 & $0,45 \pm 0,01$ & $0,01 \pm 0,001$ & $0,45 \pm 0,01$ & $0,01 \pm 0,001$ \\
\hline 4 & $0,42 \pm 0,01$ & $0,021 \pm 0,001$ & $0,4 \pm 0,01$ & $0,05 \pm 0,001$ \\
\hline 24 & $0,3 \pm 0,001$ & $0,18 \pm 0,002$ & $0,28 \pm 0,001$ & $0,13 \pm 0,002$ \\
\hline 72 & 0 & $0,51 \pm 0,01$ & 0 & $0,51 \pm 0,02$ \\
\hline
\end{tabular}

* Вихідна концентрація клітин - 1 г/л. 
можуть використовувати $\mathrm{Fe}$ (III), $\mathrm{Mn}$ (IV), $\mathrm{Cr}$ (VI), $\mathrm{NO}_{3}^{-}$, $\mathrm{Cr}_{2} \mathrm{O}_{7}^{-}$.

Досліджено вплив $\mathrm{K}_{2} \mathrm{Cr}_{2} \mathrm{O}_{7}$ i $\mathrm{KNO}_{3}$ на нагромадження біомаси і гідроген сульфіду Desulfuromonas sp. YSDS-3. За наявності у середовищі калій біхромату у концентрації 0,5 мМ $\quad$ i 1 мM i елементної сірки пригнічується нагромадження гідроген сульфіду і біомаси. За вмісту $\mathrm{K}_{2} \mathrm{Cr}_{2} \mathrm{O}_{7}$ у середовищі менше 0,5 мМ шестивалентний хром повністю відновлюється до $\mathrm{Cr}$ (III). Підвищення концентрації $\mathrm{K}_{2} \mathrm{Cr}_{2} \mathrm{O}_{7}$ приводить до зниження інтенсивності процесу його відновлення. Одночасна наявність у середовищі елементної сірки і $\mathrm{KNO}_{3}$ супроводжується зниженням сульфідогенної активності бактерій.

Досліджено відновлення сполук шестивалентного хрому іммобілізованими клітинами сірковідновлювальних бактерій Desulfuromonas sp. YSDS-3. Тривалість та інтенсивність процесу відновлення хрому залежали від концентрації фіксованих клітин, чим вища концентрація іммобілізованих клітин, тим ефективніший процес відновлення.

Отже, іммобілізовані в агар клітини бактерій Desulfuromonas sp. YSDS-3 упродовж 72 год. здатні до повної детоксикації 0,5 мM $\mathrm{Cr} \quad(\mathrm{VI})$. Збільшення концентрації клітин пришвидшує процес використання хромату у модельному розчині. Досліджені бактерії Desulfuromonas $\mathrm{sp}$. YSDS-3 $є$ перспективними для анаеробного очищення стічних вод від хромвмісних сполук.

Таким чином, сірковідновлювальні бактерії Desulfuromonas sp. YSDS-3 за біохімічними властивостями відрізняються від описаних в літературі i можуть представляти практичний інтерес, зокрема для очищення середовища від елементної сірки, нітратів i шестивалентного хрому.

\section{References}

An, T. T., Picarda, F. W. (2015). Desulfuromonas carbonis sp. nov., an $\mathrm{Fe}$ (III)-, $\mathrm{S}^{0}$ and $\mathrm{Mn}$ (IV)-reducing bacterium isolated from an active coalbed methane gas wel. International Journal of Systematic and Evolutionary Microbiology, 65, 1686-1693.

Anyanwu, C. U., Ezaka, E. (2011). Growth Responses of Chromium (VI) Tolerant Bacteria to Different Concentrations of Chromium. International Journal of Basic \& Applied Sciences IJBAS-IJENS, 11(05), 41-44.

Bilyy, O., Vasyliv, O., Hnatush, S. (2014). The Anode Biocatalyst with Simultaneous Transition Metals Pollution Control. In: Prof. Chin-Tsan Wang (Ed). Technology and Application of Microbial Fuel Cells: In Tech, 33-54.

Camargo, F. A., Bento, F. M., Okeke, B. C., Frankenberger, W. T. (2003). Chromate reduction by chromium-resistant bacteria isolated from soils contaminated with dichromate. J. Environ. Qual, 32, 1228-1233.

Derzhavna farmakopeia Ukrainy. I vydannia (2001). [The State Pharmacopoeia of Ukraine]. First Edition, Kharkiv (in Ukrainian).

EPA (U.S. Environmental Protection Agency) (1998). Toxicological review of hexavalent chromium. Washington DC, 77.

Granger, D. L., Taintor, R. R., Boockvar, K. S. (1996). Measurement of nitrate and nitrite in biological samples using nitrate reductase and Griess reaction. Methods in Enzymology, 268, 142-151.

Gumec'kyj, R. Ja., Paljanycja, B. M, Chaban, M. E. (2004). Matematychni metody $\mathrm{v}$ biolohii: teoretychni vidomosti, prohramovanyi praktykum, kompiuterni testy [Mathematical methods in biology: theoretical knowledge, practical programmable, computer tests]. Lviv, Type Center LNU ( in Ukrainian).

Honchar, T. M., Ksheminska, H. P., Patsay, I. O., Huta, O. M., Gonchar, M. V. (2008). Assay of chromium (III) in microbial cultures using chromazurol $\mathrm{S}$ and surfactants for monitoring chromatere mediation processes. Biotechnology, 1(4), 85-94.

Horton, R. N., Apel, W. A., Thompson, V. S., Sheridan, P. P. (2006). Low temperature reduction of hexavalent 5 chromium by a microbial enrichment consortium and a novel strain of Arthrobacter aurescens. II BMC Microbiologyl., 6, 5-12.

Kofanov, V. I., Ohnianyk, M. S. (2009). Normatyvnometodychne zabezpechennia vyznachennia yakosti vody pry otsintsi vplyvu na navkolyshnie seredovyshche [Regulatory and methodical provisions for water quality determination at environmental impact assessment]. Ecology of the environment and life safety, 4, 15-23 (in Ukrainian).

Lovley, D. R. (1993). Dissimilatory metal reduction. Annu. Rev. Microbiol., 47, 263-290.

Marchart, H. (1964). Uber die Reaktion von Chrom mit Diphenylcarbazid und Diphenylcarbazon. Analytica Chimica Acta, 196(30), 11-17.

Owlad, M., Aroua, M. K., Ashri, W., Daud, W., Baroutian, S. (2009). Removal of hexavalent chromium-contaminated water and wastewater: a review.Water Air Soil Pollut., 200, $59-77$.

Postgate, J. R. (1984). The sulfate- reducing bacteria. $2^{\text {nd }}$ ed. Cambridge University: Cambridge.

Seghezzo, L., Zee man, G., van Lier, J. B. et al. (1998). A review: the anaerobic treatment of sewage in UASB and EGSB reactors. Bioresour. Technol, 65, 175-190.

Shanna, D. C., Forster, C. F. (1996). Cleaning of sewages from salts of chrome by carbon absorbent. Water S. Afr., 2, $153-160$

Sholiak, K. V., Peretyatko, T. B., Gudz, S. P. (2013). Aktseptory elektroniv dlia sulfatvidnovliuvalnykh bakterii Desulfomicrobium sp. y protsesi okysnennia orhanichnykh spoluk [Electron acceptors for sulphate-reducing bacteria Desulfomicrobium sp. in the process of oxidation of organic compounds]. Studia Biologica, 7(2), 57-64 (in Ukrainian).

Sholiak, K. V., Peretyatko, T. B., Gudz, S. P. (2014). Patent Ukrainy na korysnu model № 71666. Sposib ochystky stichnykh vod vid shestyvalentnoho khromu mikroorhanizmamy [Method of sewage purification from hexavalent chromium with microorganisms] With Publ. 25.07, 4 (in Ukrainian).

Smith, W. L., Gadd, G. M. (2000). Reduction and precipitation of chromate by mixed culture sulphate reducing bacterial biofilms. Appl. Microbiol., 88, 983-991.

Sugiyama, M. (2002). United States Patent, № 6340596. Reagent composition for measuring hydrogen sulfide and method for measuring hydrogen sulfide.

Vasylinych, T. M. (2011). Ochyshchennia stichnykh vod shkirianoho vyrobnytstva vid ioniv khromu [Cleaning of sewage from the production of chrome ions]. Herald of Khmelnytskyi national university, 1, 228-231 (in Ukrainian).

Chayka, O., Peretyatko, T., Gudz, S. (2010). Sirkovidnovliuvalni bakterii vodoim Yavorivskoho sirkovoho rodovyshcha [Sulfur reducing bacteria of Yazivske sulfur deposit]. Scientific Bulletin of the Uzhgorod University. Series Biology, 28, 52-55 (in Ukrainian). 